\title{
SISTEM INFORMASI PENATALAYANAN JEMAAT GEREJA HKBP KUPANG BERBASIS WEB
}

\author{
Gloria Manulangga ${ }^{1}$, Sara Gultom ${ }^{2}$
}

\begin{abstract}
Abstrak :
Dengan semakin berkembangnya Teknologi Informasi, pemakaian komputer sebagai pengolah dan pemroses data sangat diperlukan dalam sebuah instansi perusahaan atau lembaga baik itu komersial maupun non komersial. Salah satu lembaga yang memerlukan komputer sebagai pengolah dan pemroses data adalah gereja. Sistem informasi penatalayanan jemaat gereja HKBP Kupang berbasis web adalah sebuah sistem yang bertujuan untuk membantu pihak gereja dalam mengolah data jemaat, jadwal ibadah lingkungan, dan petugas ibadah minggu. Sistem informasi penatalayanan jemaat ini diperuntukan kepada jemaat HKBP Kupang untuk mempermudah penyebaran informasi. Tugas Akhir dengan judul Sistem Informasi Penatalayanan Jemaat Gereja HKBP Kupang Berbasis Web ini menampilkan informasi jemaat, jadwal ibadah lingkungan, petugas ibadah minggu, profil dan sejarah gereja HKBP Kupang.
\end{abstract}

Kata Kunci : Gereja, HKBP, Sistem Informasi Jemaat.

\section{PENDAHULUAN}

Perkembangan teknologi informasi saat ini sangat berkembang pesat. Melalui teknologi informasi semua orang dapat menggunakan sistem informasi dengan mudah dan cepat. Salah satu sistem informasi yang saat ini berkembang adalah website. Dengan adanya website dapat membantu banyak orang untuk memperoleh informasi secara umum, dan memberi wawasan yang lebih luas.

Website saat ini terus berkembang untuk memenuhi kebutuhan informasi di berbagai bidang kehidupan. Disamping penyebaran informasi menggunakan website lebih merata, dengan website informasi dapat mengalir secara efektif dan efisien. Keunggulan ini yang menjadikan teknologi informasi saat ini banyak berperan serta dalam segala bidang dan aspek kehidupan, sebuah instansi perusahaan atau lembaga baik itu komersial maupun lembaga non komersial. Salah satu lembaga yang memer- lukan sistem komputer sebagai pengolah dan pemroses data adalah gereja.

Gereja HKBP resot Kupang adalah sebuah Huria Kristen Batak Protestan yang berada pada distrik XVII Indonesia Bagian Timur. Pada dulunya gereja HKBP resot Kupang ini masih menjadi satu bagian dengan HKBP resot Bali, namun setelah banyak warga jemaat gereja yang tinggal di daerah NTT dan sekitarnya sehingga Majelis Sinode memutuskan agar HKBP resot Kupang memisahkan diri dari HKBP resot Bali.

HKBP resot Kupang memiliki jumlah jemaat 348 jiwa terdiri dari 104 keluarga, pendataan jemaat di gereja ini sudah menggunakan sistem komputerisasi, namun masih menggunakan aplikasi Ms.Officee Word dan Ms.Officee Excel. Dan ada beberapa data yang pendataannya masih menggunakan sistem manual yaitu ada beberapa data yang masih di simpan di dalam buku besar gereja, sehingga untuk mengetahui data jemaat yang ada di setiap ligkungan harus membuka kembali berkas-berkas atau data-data

Manulangga ${ }^{I}$, Adalah Dosen Teknik Komputer dan Jaringan, Politeknik Negeri Kupang 
yang di input secara manual. Selain kesulitan mengetahui data jemaat, penulis juga menemukan masalah lainnya, yaitu dalam mengelolah jadwal ibadah lingkungan dan petugas ibadah minggu yang kurang efektif dan efisien. Dimana media yang digunakan untuk menyampaikan informasi tersebut masih menggunakan warta gereja yang hanya bisa di dapatkan pada hari minggu saat pelaksanaan ibadah mingguan.

Merujuk pada latar belakang tersebut diatas, maka penulis mengajukan sebuah proposal penelitian Sistem Informasi Penatalayanan Jemaat Gereja HKBP Kupang Berbasis Web untuk dapat membantu dan memudahkan jemaat dalam mendapatkan informasi data jemaat, jadwal ibadah lingkungan, dan jadwal petugas ibadah mingguan tidak membutuhkan banyak waktu dan efisien serta mudah diterima dan digunakan oleh gereja.

\section{TINJAUAN PUSTAKA}

Untuk penelitian ini penulis telah melakukan beberapa kajian atas penelitian terdahulu yang relevan dengan penelitian penulis, yaitu : a. Mario Wangga. (2012). Sistem Informasi Pendataan Umat Di Gereja St. Matias Rasul. Pembuatan aplikasi ini menggunakan Netframework 3.5, Delphi Embarca-dero 2010, Microsoft Visio 2007, Microsoft Access 2007. Sistem informasi ini menghasilkan sebuah sistem pendataan umat yang baik dan efisien dalam penyajian informasi tentang umat baik berupa data umat, informasi kelompok umat basis (KUB) dan profil gereja.

b.Steven, Davidz. (2013). Aplikasi Sistem Pendataan Jemaat Dan Majelis Gpib Anugerah Bekasi Menggunakan Java Dan Mysql. Aplikasi ini dibuat guna untuk memperoleh kemudahan dalam mengakses informasi jemaat dan majelis, data setiap jemaat di masing-masing sektor, mengelola data jemaat dan majelis GPIB Anugerah Bekasi. Pembuatan aplikasi ini menggunakan Java dan Mysql.

c. Volvo Sihombing, (2014). Sistem Informasi Pengolahan Data Jemaat Gereja Huria Kristen Batak Protestan (HKBP) Yogyakarta berbasis web. Sistem Informasi Pengolahan Data Jemaat Gereja Huria Kristen Batak Protestan Yogyakarta dapat memberikan kemudahan dalam pendataan jemaat, konseling yang ada di gereja HKBP dengan menggunakan aplikasi ini. Pembuatan aplikasi ini menggunakan Adobe Dreamweaver CS5, dan PHP MySQL

\section{METODE PENELITIAN}

\subsection{Hardware dan Software}

Komponen pendukung untuk membangun sebuah website adalah sebagai berikut:

\section{Hardware (perangkat keras)}

a.Labtop accer aspire $4738 \mathrm{Z}$

b. Memory DDR 3

c. Hard disk $320 \mathrm{~GB}$

d.Intel core i3

e. LCD 14 inc

2.Software (perangkat lunak)

a.Windows 732 bit

b.Xampp server win32-1.7.7 digunakan untuk membuat database dengan MySQL.

c. Adobe Dreamweaver CS3 adalah software yang digunakan untuk mendesain halaman web yang akan dirancang.

\subsection{Metode Perancangan Sistem}

Metode yang digunakan dalam pembuatan Sistem Informasi Penatalayanan Jemaat Gereja HKBP Kupang Berbasis Web adalah model waterfall.

\subsection{Kebutuhan Sistem}

1.Kebutuhan Input

Adapun kebutuhan input dari Sistem Informasi Penatalayanan Jemaat Gereja HKBP Kupang Berbasis Web antara lain :

a. Data jemaat

b.Data keluarga

c. Data lingkungan

d.Data organisasi

e. Data majelis

f. Data ibadah lingkungan

g.Data ibadah minggu. 
2.Kebutuhan output

Adapun kebutuhan output Sistem Informasi Penatalayanan Jemaat Gereja HKBP Kupang Berbasis Web akan menghasilkan tampilan informasi kepada jemaat dan laporan kepada sekretariat gereja, antara lain:

a.Laporan Jemaat

b.Laporan Lingkungan

c.Laporan Anggota Organisasi

d.Laporan Ibadah Lingkungan

e. Laporan Ibadah Minggu

f. Laporan Keluarga

g.Laporan Majelis

\subsection{Perancangan Sistem}

1.Diagram Konteks

Context diagram dari sistem informasi data jemaat gereja HKBP Kupang, seperti ditunjukan pada gambar berikut ini:
2.Data Flow Diagram
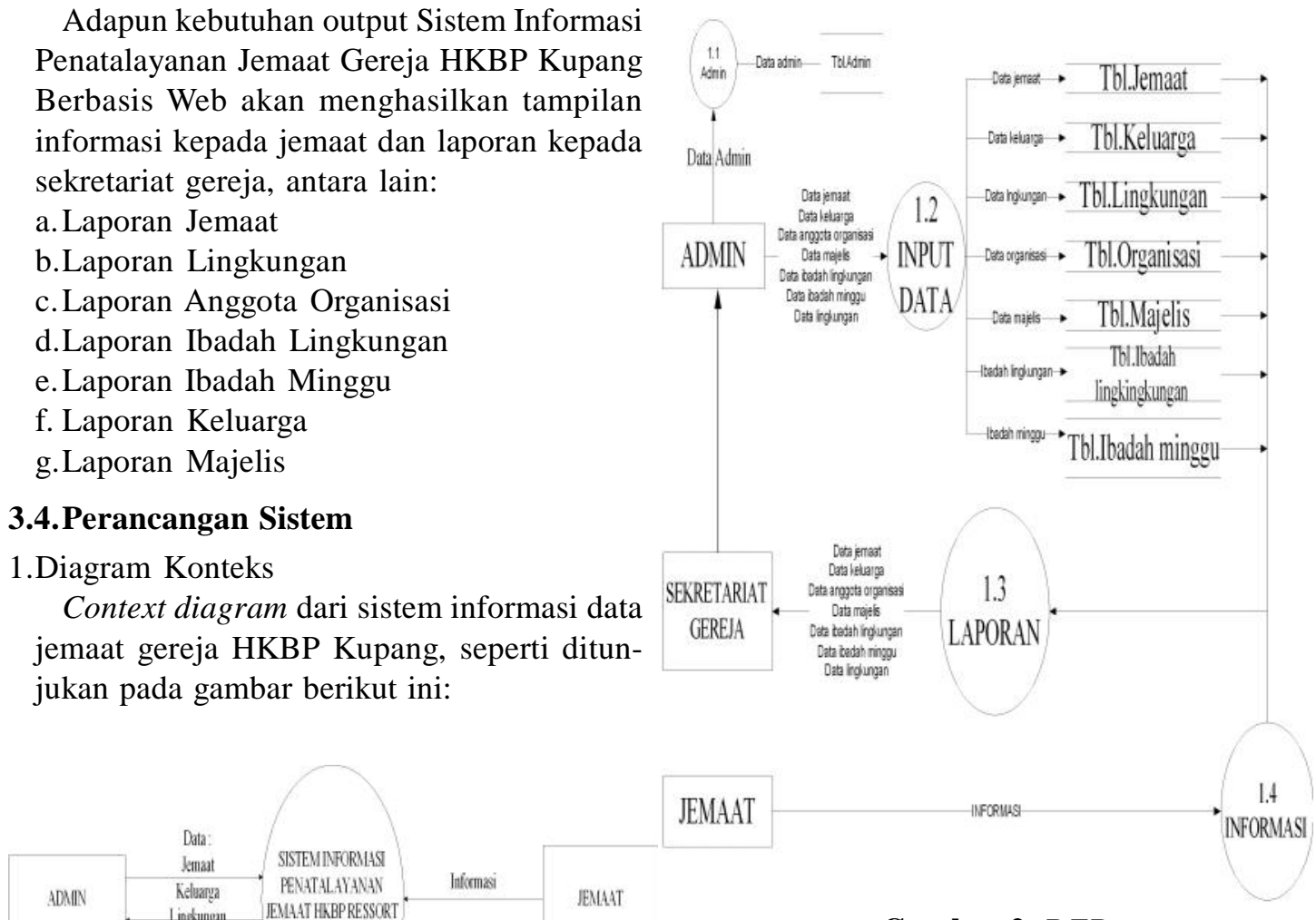

Gambar 2. DFD

3.ERD

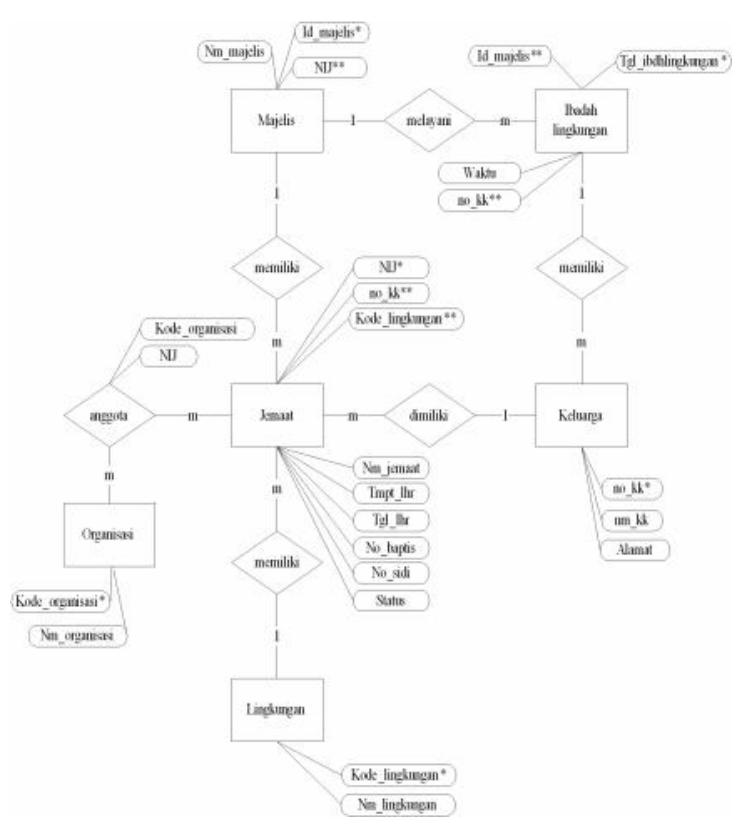

Gambar 3. $E R D$ 


\section{PEMBAHASAN}

1.Halaman Beranda

Halaman ini merupakan halaman awal pada website gereja HKBP Kupang.

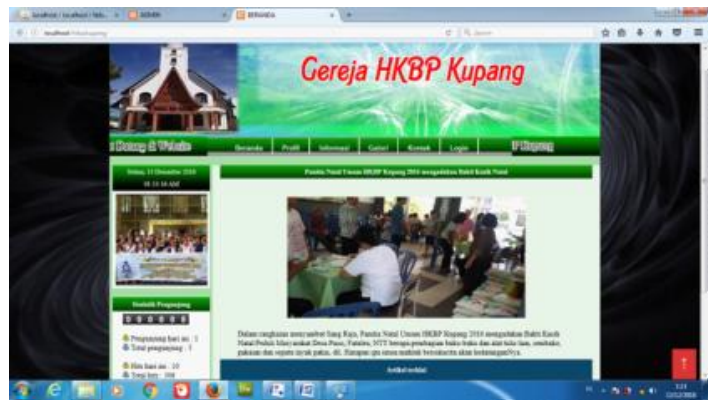

Gambar 4. Tampilan halaman beranda HKBP

2.Halaman Informasi Jemaat

Pada halaman informasi ini, berisi tentang data jemaat. Jemaat dapat melihat informasi yang diberikan oleh admin.

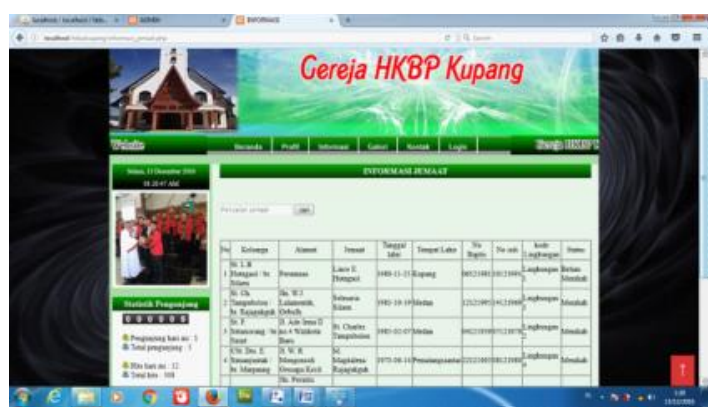

Gambar 5. Tampilan halaman Informasi Jemaat

3.Halaman Informasi Ibadah Lingkungan Pada halaman ini, jemaat dapat melihat informasi jadwal ibadah lingkungan yang telah diproses oleh sistem.

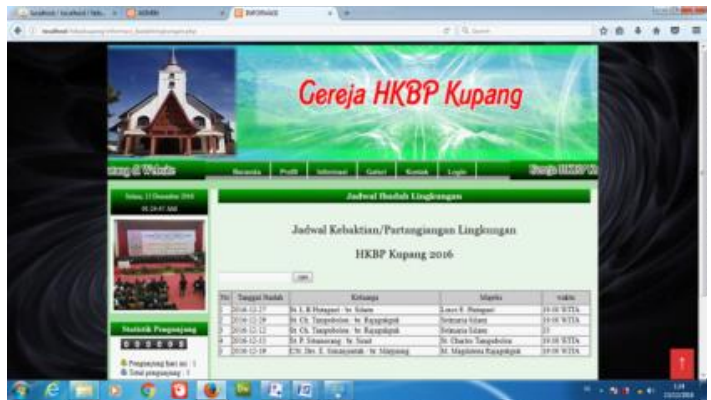

Gambar 6. Tampilan halaman Informasi ibadah lingkungan
4.Halaman Informasi Ibadah minggu

Pada halaman ini, jemaat dapat melihat informasi petugas ibadah minggu yang telah diproses oleh sistem.

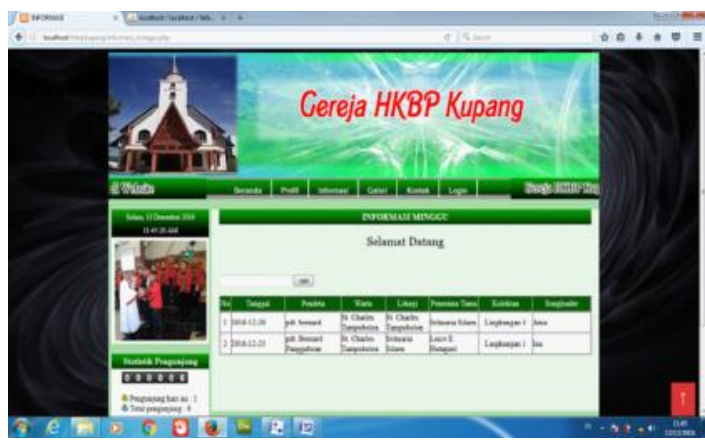

Gambar 7. Tampilan halaman Informasi Petugas Ibadah Minggu

\section{KESIMPULAN DAN SARAN}

\subsection{Kesimpulan}

Berdasarkan uraian permasalahan dan pemecahannya pada bab sebelumnya, maka dapat diambil kesimpulan sebagai berikut:

1.Sistem Informasi Penatalayanan Jemaat Gereja HKBP Kupang Berbasis Web dibuat dengan PHP dan MySql

2.Dalam proses perancangan sistem informasi ini menghasilkan output sebuah database bernama hkbp_kupang dengan tabel-tabel yaitu jemaat, keluarga, lingkungan, organisasi, majelis, ibadah_lingkungan, ibadah_minggu, dan admin.

3.Dalam sistem informasi ini menampilkan data jemaat, data keluarga, data majelis, data anggota organisasi, data ibadah_lingkungan, data ibadah_minggu yang di tampilkan sebagai informasi untuk jemaat dan laporan kepada pihak sekretariat gereja.

4.Sistem Informasi Penatalayanan Jemaat Gereja HKBP Kupang dapat di jalankan menggunakan Mozila Firefox, Crome, dan Opera browser. 


\subsection{Saran}

Untuk penelitian selanjutnya diharapkan bisa memperbaiki kelemahan dan kekurangan yang terdapat pada penelitian tugas akhir ini. Beberapa saran yang diberikan adalah perlu dikembangkan sistem informasi ini dengan menambahkan informasi data keuangan.

\section{DAFTAR PUSTAKA:}

Anonim,2014.http://satriamecha.blogspot.co.id/ $2014 / 08 /$ pengertian-erd-entityrelationship.html. diakses pada tanggal 9 september 2016.

Anonim,2015.http://www.duniailkom.com/ pengertian-dan-fungsi-php-dalampemograman-web/. Diakses tanggal 20 Agustus 2016.

Danis F. 2014. Xampp dan Fungsinya, Jakarta: Andi.
Kadir, Abdul. 2002. Pengenalan Sistem Informasi. Yogyakarta: Andi.

Kendall, K.E, dan J.E. Kendall. 2003. Analisa dan Perancangan Sistem, Edisi-5, Jilid I Dan Jilid II. Jakarta: Alih Bahasa Thamrin Abdul Hafedh P.T. Indeks.

Ladjamudin, Bin Al-bahra. 2006. Analisis dan Desain Sistem Informasi. Yogyakarta: Graha Ilmu.

Nugroho, Bunafit. 2004. Pemograman Web dengan PhpMySql. Yogyakarta: Krisnawati.

Puspitasari, Heni A. 2010. Pemograman Web Data base. Penerbit TP. Skripto Media Creative, Jakarta.

Steve, Brown. 1999. Internet dan World Wide Web. Jakarta: Media Komputindo.

Zaki, Ali. 2008. Web Server, HTTP, Perangkat Lunak. Surabaya: Krisnawati. 